\title{
The Arab Spring: Membaca Kronologi dan Faktor Penyebabnya
}

\author{
Ahmad Sahide \\ Agama dan Lintas Budaya, Minat Kajian Timur Tengah, \\ Sekolah Pascasarjana Universitas Gadjah Mada \\ ahmadsahidie@gmail.com \\ Submitted: 23 March 2015, Accepted: 10 Mei 2015
}

\section{Syamsul Hadi}

Fakultas IImu Budaya

Universitas Gadjah Mada Yogyakarta

\section{Siti Muti’ah Setiawati}

Fakultas IImu Sosial dan IImu Politik

Universitas Gadjah Mada Yogyakarta

\section{Bambang Cipto}

Fakultas IImu Sosial dan IImu Politik

Universitas Muhammadiyah Yogyakarta

\begin{abstract}
The Arab States has faced political turbulence since January of 2011. This political event began by suicide action from a youth named Mohammed Bouazizi (Tunisia) until it spread to the other states such as Egypt, Syria, and the like. The political event became the beginning of the people power to fight against dictator regime in most of the Arab States. The rise of the people power succeeded to end the power of some tyrannical regimes, beginning from Tunisia, Zein Al-Abidin Ben Ali, followed by the end of Mubarak's regime in Egypt, Syria still having political turbulence until now in order to overthrow Bashar al-Assad's regime, and some other Arab States which can't be irrespective from the political turbulence. This political event is called "The Arab Spring", that is the coming of the hope for the better life with a democratic system. This writing tries to discuss chronology of that event and also tries to find out factors becoming cause of the political turbulence.

Key Words: The Arab Spring, regime, people power, politic.
\end{abstract}

\begin{abstract}
Abstrak
Negara-negara Arab mengalami kegoncangan politik sejak Januari 2011. Peristiwa politik yang dimulai aksi bunuh diri seorang permuda bernama Mohammed Bouazizi (Tunisia) hingga merambat ke negara-negara Arab lainnya, seperti Mesir, Suriah, dan lain-lain. Peristiwa politik tersebut menjadi awal kebangkitan gerakan massa (people power) untuk bangkit melawan rezim-rezim diktator di sebagian besar negara-negara Arab. Kebangkitan gerakan massa itulah yang mengakhiri kekuasan beberarapa pemimpin tiran, dimulai dari Tunisia, Zein Al-Abidin Ben Ali, disusul oleh berakhirnya era Mubarak di Mesir, Suriah yang sampai hari ini masih terus bergejolak untuk melawan rezim Bashar al-Assad, dan beberapa negara Arab lainnya yang tidak terlepas dari gejolak politik tersebut. Peristiwa politik ini disebut dengan istilah "The Arab Spring" atau Musim Semi Arab, yaitu musim hadirnya harapan untuk hidup lebih baik dengan sistem yang demokratis. Tulisan ini mencoba mengulas kronologi peristiwa tersebut serta melacak faktor-faktor yang menyebabkan terjadinya The Arab Spring.
\end{abstract}

Kata Kunci: The Arab Spring, rezim, people power, politik.

\section{PENDAHULUAN}

"The Arab Spring", Musim Semi Arab, adalah bahasa politik yang mulai populer dalam kancah politik internasional, terutama di negara-negara Arab, sejak awal Januari 2011 lalu. Istilah yang menunjukkan kejatuhan berderet rezim pemimpin-pemimpin otoriter dunia Arab, dimulai dari Tunisia, Zein AlAbidin Ben Ali (Ben Ali), diikuti Mesir dengan

tergulingnya Hosni Mubarak, kemudian ke Libya, yang berhasil mengakhiri era kediktatoran Moammar Khadafy yang sudah berlangsung kurang lebih 40 tahun lamanya, dilanjutkan oleh Yaman, Bahrain, dan Suriah yang masih berlangsung sampai sekarang.

The Arab Spring yang menjadi awal kebangkitan harapan akan kehidupan yang lebih baik dan lebih 
demokratis di kawasan Timur Tengah, terutama dunia Arab, justru menampilkan wajah yang lebih menyeramkan. Musim Semi itu kini telah mengorbankan lebih dari 250.000 orang di Suriah sampai saat ini karena konflik yang terus berkepanjangan. Menurut Komisi Tinggi PBB untuk Pengungsi(UNHCR), lebih dari 7,6 juta warga Suriah menjadi pengungsi di negara mereka sendiri dan 4,2 juta mengungsi ke sejumlah negara di sekitar Suriah. Organisasi Internasional untuk Migrasi (IOM) menyebutkan, 893.970 orang di antaranya mengalir ke Eropa (Kompas, 9/12/2015)

Rakyat Arab menyebut peristiwa politik penting ini dengan sebutan al-Tsaurat al-Arabiyyah yaitu revolusi yang akan mengubah tatanan menuju masyarakat dan bangsa ideal setelah sekian lama dipimpin dengan sistem otoriter, dengan kekuasaan yang tidak dibatasi, yang mengekang kebebasan masyarakat serta melahirkan kesenjangan antara elite (penguasa), yang hidup mewah, dengan rakyat yang miskin. Orang Barat menyebutnya dengan Arab Springs (Musim Semi Arab/ al-Rabi' al-Arabiy) yaitu musim yang menjadi titik awal pertumbuhan demokrasi di negara-negara Arab (Burdah, 2014: 21). Penulis, dalam tulisan ini, melakukan analisis teoritik terhadap The Arab Spring itu sendiri dan kemudian mengkaji secara mendalam faktor-faktor yang melatarbelakangi gejolak tersebut.

Dalam melakukan pembacaan terhadap The Arab Spring setelah bergolak, penulis melakukan analisis dengan menggunakan teori perubahan sosial. Dalam teori perubahan sosial, August Comte (1798-1857) membaginya dalam dua konsep penting; yaitu Social Static (bangunan struktural) dan Social Dynamics (dinamika struktural). Bangunan struktural merupakan hal-hal yang mapan, berupa struktur yang berlaku pada suatu masa tertentu. Bahasan utamanya mengenai struktur sosial yang ada di masyarakat yang melandasi dan menunjang orde, tertib, dan kestabilan masyarakat. Statika sosial ini kemudian disepakati oleh anggota masyarakat dan karena itu disebut sebagai 'kemauan umum' atau 'volonte general' (Salim, 2002:9).

Dengan kata lain, dapat dipahami bahwa hasrat dan kodrat manusia adalah persatuan, perdamaian, kestabilan, atau keseimbangan. Tanpa unsur-unsur struktural ini, kehidupan manusia tidak dapat berjalan. Akan selalu terjadi pertengkaran dan perpecahan mengenai hal-hal yang sangat mendasar, sehingga kesesuaian paham sukar terbangun. Sementara, dinamika sosial merupakan hal-hal yang berubah dari satu waktu ke waktu yang lain, yang dibahas adalah dinamika sosial dari struktur yang berubah dari waktu ke waktu. Dinamika sosial adalah daya gerak dari sejarah tersebut, yang pada setiap tahapan evolusi manusia mendorong ke arah tercapainya keseimbangan baru yang tinggi dari satu masa (generasi) ke masa berikutunya (Salim, 2002: 9-10).

Teori perubahan sosial inilah yang penulis gunakan sebagai pisau analisis dalam menjawab pertanyaan mengapa The Arap Spring bergejolak di negara-negara Arab sejak 2011 lalu serta apa yang menjadi faktorfaktornya? Dalam artian bahwa The Arab Spring merupakan dinamika social yang bergerak ke arah tercapainya keseimbangan baru yang tinggi dari satu masa (generasi) ke masa berikutunya.

\section{METODE PENELITIAN}

Tulisan ini memfokuskan pada kajian kepustakaan. Dalam kajian tersebut, penulis membaca karya-karya yang terkait dengan tema yang diangkat, The Arab Spring dengan lebih fokus mengkaji di tiga negara, yaitu Tunisia, Mesir, dan Suriah. Penulis memilih ketiga Negara tersebut karena masing-masing dapat merepresentasikan gejolak dan transisi demokratisasi yang berbeda. Tunisia merepresentasikan sebagai negara yang berhasil dalam transisi demokrarisnya, sementara Mesir mengalami kegagalan di tengah jalan melalui proses kudeta, tetapi telah berhasil menggulingkan rezim Hosni Mubarak yang otoriter. Adapun Suriah belum berhasil menggulingkan rezim Bashar al-Assad yang otoriter.

Sumber-sumber lain dalam bentuk artikel, berita, dan rekaman atau video terkait menjadi data penunjang penelitian untuk memahami lebih jauh bergejolaknya The Arab Spring sejak 2011 lalu sebagai sebuah gerakan untuk melakukan perubahan sosial politik. Data-data yang ada penulis olah dengan 
menggunakan pendekatan critical reading. Critical reading merupakan salah satu pendekatan post-kolonial sebagai perangkat analisis. Critical reading tidak dimaksudkan untuk explain what a text means, but to elaborate it into a new text. Di samping itu, penulis juga beberapa kali mengadakan forum diskusi untuk membahas tema ini.

Karena tulisan ini mencoba membaca gejolak The Arab Spring sebagai sebuah gerakan perubahan sosial politik, maka penulis melakukan kajian kepustakaan dengan membaca kronologi lahirnya gejolak politik tesebut, situasi sosial politik dari ketiga negara perkembangannya, dan terus mengikuti perkembangan isu-isu yang terkait gerakan ini hingga hari ini. Hasil dari kajian kepustakaan itulah sehingga tulisan ini lahir dan dapat dikonsumsi oleh publik secara luas sebagai khasanah pengayaan keilmuan.

\section{PEMBAHASAN}

The Arab Spring bukanlah peristiwa yang terjadi begitu saja dan bersfat konstan. Peristiwa ini dilatarbelakangi oleh kondisi sosial politik dan ekonomi yang berlangsung di Negara-negara Arab jauh sebelum gejolak tersebut terjadi. Oleh karena itu, pada bagian ini, penulis mengulas kronologi The Arab Spring, baru kemudian melihat faktor-faktor apa saja yang menjadi penyebab dari peristiwa yang membuka lebih lebar keran demokratisasi di negara-negara Arab tersebut.

\section{KRONOLOGI THE ARAB SPRING}

\section{Gejolak The Arab Spring adalah peristiwa yang} bermula dari Tunisia ketika seorang pemuda 26 tahun, Mohammed Bouazizi, melakukan protes terhadap kekejaman pemerintahan lokal di bawah rezim otoriter Ben Ali. Bouazizi melakukan aksi bakar diri yang menarik perhatian seluruh negeri, bahkan dunia, pada tanggal 17 Desember 2010. Pada hari itu, Jum'at, 17 Desember, pemuda 26 tahun ini berangkat dari rumahnya di pagi hari untuk melakukan aktivitas penopang hidupnya, menuju gerobak tempatnya berjualan sayur-sayuran di Sidi Bouzid, 190 mil (300 $\mathrm{km}$ ) selatan Tunisia. Bouazizi dan gerobaknya telah menjadi target razia aparat karena dianggap berjualan tanpa ijin (Angrist, 2011: 75).
Bouazizi sebenarnya adalah lulusan universitas yang terpaksa menerima hidup dengan pekerjaan kasar tersebut (sebagai pedagang kaki lima/PKL) (Goldstein, 2011:69). Ibu dari Mohammed Bouazizi mengatakan bahwa aksi bakar diri tersebut bukan karena faktor ideologi atau politik. Aksi tersebut murni demi harkat dan martabatnya sebagai manusia. Menurut ibu Bouazizi, merupakan sebuah kehinaan bagi anaknya bahwa dia menderita (dimaki dan disiksa oleh aparat) yang tidak lagi dapat dia toleransi (Joseph, 2012: 9).

Bouazizi sendiri harus menyetor denda 10 dinar (upah satu hari, setara dengan 7 USD) karena tidak memiliki ijin usaha. Bouazizi tidak punya pilihan lain selain terus berjualan sebagai pedagang kaki lima (PKL) meskipun tidak membayar denda. Terus berjualan tanpa ijin dan juga tidak membayar denda itulah yang membuat dia dan gerobaknya menjadi salah satu target razia aparat setempat. Sudah menjadi hal yang lazim di Sidi Bouzid bahwa para PKL harus memberikan uang suap kepada aparat untuk tetap bisa berjualan, namun pada hari itu Bouazizi sedang tidak mempunyai uang untuk menyuap aparat (Tamburaka, 2011: 25).

Saat sedang menata dan merapikan barang dagangannya itulah, Faida Hamdi (45), oknum aparat yang bertugas di daerah tersebut, bersama dua rekannya datang dan memberi tahu Bouazizi bahwa ia tidak memiliki ijin sehingga gerobaknya akan disita dan juga Bouazizi harus membayar denda. Bouazizi tidak mengalah begitu saja sehingga terjadi pertengkaran adu mulut antara dirinya dan oknum aparat wanita bersama temannya tersebut. Bouazizi ditampar, wajahnya diludahi, timbangannya disita, dan gerobaknya juga disita serta mendiang ayahnya dihina oleh aparat tersebut (Tamburaka, 2011: 25). Begitulah perlakuan aparat terhadap Bouazizi yang lemah itu.

Situasi tidak berdaya atas kesewenangan aparat terhadap dirinya itu membuatnya mengadu pada Gubernur Sidi Bouzid. Pengaduan Bouazizi ini tidak mendapatkan perhatian serius dari Gubernur, bahkan Gubernur menolak untuk melihat dan mendengarkan pengaduan nasibnya. Karena frustrasi dengan situasi yang dihadapinya itulah sehingga pemuda 26 tahun ini mengatakan, "Jika Anda tidak mendengarkan saya. 
Saya akan bakar diri saya sendiri." Lontaran kalimat yang diucapkan oleh Bouazizi ini ternyata bukan hanya ancaman. Ia benar-benar nekat melakukan aksi yang di luar nalar akal sehat manusia pada umumnya. Kurang dari satu jam kemudian, ia kembali ke kantor Gubernur tanpa ditemani satu pun anggota keluarganya. Bouazizi datang dengan membawa dua botol bensin kemudian membakar dirinya di depan kantor Gubernur pemerintah daerah, Sidi Bouzid (Tamburaka: 25-26). Aksi bakar diri yang dilakukan oleh Bouazizi merupakan pilihan hidup terbaik baginya yang tidak lagi punya harapan hidup serta tidak tahan menghadapi hidup yang hampir setiap hari diperlakukan sewenang-wenang dan dihina oleh aparat.

Bouazizi sempat dilarikan ke rumah sakit setelah membakar dirinya dan juga sempat dipindahkan ke rumah sakit kota Ben Arous, dekat Tunis. Di sana ia menjalani perawatan di Trauma Centre dan Burn. Presiden Tunisia, Zein al-Abidin Ben Ali, sempat menjenguknya di rumah sakit (Tamburaka: 27-28). Namun semua sudah terlambat dan tidak mampu menyelamatkan nyawa pedagang kaki lima tersebut serta menyelamatkan kekuasaan Ben Ali. Tepatnya pada tanggal 4 Januari 2011 atau 17 hari telah aksinya tersebut, Bouazizi menghembuskan nafas terakhirnya. Pada hari itu, kurang lebih 5000 orang ikut ambil bagian dalam proses pemakamannya. Keesokan harinya, Bouazizi dimakamkan di pemakaman Bennour Garat, 10 mil dari Sidi Bouzid (Tamburaka: 27).

Aksi bakar diri (self-immolation) yang dilakukan oleh Bouazizi segera mendapatkan perhatian secara luas, melalui pemberitaan media-media nasional dan internasional, yang diikuti oleh demonstrasi yang mengguncang kekuasaan di tangan rezim otoriter di negara-negara Arab, bukan hanya di Tunisia (Campante dan Davin Chor, 2012: 167).

Kemarahan publik tidak hanya meluas setelah Bouazizi menghembuskan nafas terakhirnya, tetapi hanya sehari berselang ia membakar dirinya massa kemudian turun melakukan unjuk rasa yang menyebabkan kerusuhan di kota tersebut, bahkan aparat sempat kewalahan mengatasi kerusuhan yang terjadi dalam aksi unjuk rasa tersebut. Sejumlah jejaring sosial seperti Facebook dan YouTube menyorot beberapa gambar dari aksi tersebut. Dalam upayanya untuk memadamkan kerusuhan itulah, Presiden Ben Ali mengunjungi Bouazizi di rumah sakit sebelum meninggal (Tamburaka: 28). Namun demikian, kunjungan Ben Ali tidak berhasil memadamkan semangat perlawanan dari rakyatnya.

Setelah kematian Bouazizi, gerakan perlawanan terus terjadi hingga kekerasan meningkat terusmenerus, bahkan semakin mendekati ibukota negara, Tunis. Pada tanggal 27 Desember 2010, sekitar 1.000 warga bersama-sama dengan penduduk Sidi Bouzid mengekspresikan solidaritas dengan menyerukan suatu aksi bersama menentang pemerintahan. Pada saat yang sama, sekitar 300 pengacara mengadakan sebuah aksi demo dekat pemerintahan istana di Tunis. Demonstrasi kembali dilanjutkan pada tanggal 29 Desember (Tamburaka: 29-30).

Pada tanggal 30 Desember 2010, aparat membubarkan demonstrasi damai di Monastir dengan menggunakan kekerasan untuk mengganggu demonstrasi lebih lanjut di Sbikha dan Cebba. Momentum kembali untuk melanjutkan dengan demonstrasi pada tanggal 31 Desember 2010, ketika dilakukan demonstrasi dan pertemuan umum oleh pengacara di Tunisia dan kota-kota lainnya menyusul seruan oleh Kelompok Pengacara Nasional Tunisia, Mokhtar Trifi, selaku Presiden Tunisia Liga Hak Asasi Manusia/Ligue Tunisienne des Droits de l'Homme (LTDH) yang mana mengatakan bahwa pengacara di Tunisia telah secara kejam dianiaya dan "dipukuli" (Tamburaka: 30-31).

Tanggal 3 Januari 2011, demonstrasi dilakukan dekat kota Thala dengan mengusung isu pengangguran dan tingginya biaya hidup, namun akhirnya demonstrasi tersebut berubah menjadi anarkis (kekerasan). Demonstrasi yang diikuti kurang lebih 250 orang tersebut diikuti sebagian besar mahasiswa sebagai upaya untuk mendukung aksi para demonstran di Sidi Bouzid. Sebagai responsnya, para pengunjuk rasa dilaporkan telah membakar ban dan menyerang kantor Konstitusi Demokratik Rally. Menanggapi aksi 
demonstrasi yang berujung kerusuhan, aparat mengirim pasukan anti huru-hara untuk membubarkan para demonstran karena merusak bangunan, membakar ban, membakar sebuah bus, dan membakar dua mobil kelas pekerja pinggiran dari Ettadhame-Mnihla di Tunis. Aparat militer juga dikerahkan di banyak kota di seluruh negeri (Tamburaka: 31).

Banyak faktor yang menjadi pemicu sehingga aksi protes massa tesebut terus berlangsung di seluruh negeri, termasuk pemberitaan masif dari Al-Jazeera yang diambil langsung oleh masyarakat Tunisia, melalui kamera telepon seluler dan kemudian disebarkan melalui YouTube dan Facebook dan kemudian disebarkan lagi melalui Twitter, bahkan kabel pemberitaan Wikileaks (Goldstein: 69). Peran media yang memberitakan kekejaman aparat rezim di bawah rezim Ben Ali tersebutlah yang menjadi faktor penting dan utama bangkitnya gerakan massa untuk menggulingkan Ben Ali yang tidak lagi mampu ditangani oleh aparatur negara.

Inilah era kebangkitan gerakan sipil (people power) untuk melawan kendali negara yang tidak pernah terjadi sebelumnya sejak Tunisia merdeka pada tahun 1956. Menanggapi bangkitnya kekuatan sipil itulah sehingga Ben Ali menyatakan bahwa negaranya dalam keadaan darurat dan dia juga bernjanji untuk mengadakan pemilihan legislatif baru dalam waktu enam bulan (Tamburaka: 33). Ben Ali juga berjanji, dalam pidatonya menyambut demonstrasi, akan menurunkan harga pangan, menjamin kebebasan politik, media massa, dan berjanji akan mundur dari jabatan presiden pada tahun 2014. Saat itu, Ben Ali mengatakan kepada rakyatnya untuk menciptakan sekitar 300.000 lapangan pekerjaan dalam jangka waktu dua tahun untuk mengurangi tingkat pengangguran (Kompas, 15/01/2011).

Janji politik yang diucapkan oleh Ben Ali tersebut sebagai bagian dari upayanya untuk meredam kemarahan publik terhadap rezim otoritarian yang dia bangun sejak menggulingkan Bourguiba pada tanggal 7 November 1987. Namun demikian, upaya politik yang dilakukan oleh Ben Ali, termasuk dengan mengunjungi Bouazizi di rumah sakit sebelum meninggal, tidak membuahkan hasil. Demonstrasi terus berlangsung di seluruh negeri, bahkan beberapa tokoh yang selama ini menjadi bagian dari rezim Ben Ali membelot.

Era kekuasaan Ben Ali yang dibangun dengan tangan besi berakhir setelah menyatakan mundur dari kursi kekuasaannya sebagai Presiden Tunisia pada tanggal 14 Januari 2011, sekitar pukul 16.00 waktu setempat di mana pernyataannya didelegasikan kepada Perdana Menteri (PM) Mohamed Ghannouchi untuk bertindak sebagai kepala negara "sementara" selama ketidakhadirannya. Dalam pernyataannya di televisi Ghannouchi mengatakan, "Karena presiden untuk sementara tidak dapat melaksanakan tugasnya dan telah diputuskan bahwa PM akan memegang sementara tugas presiden" (Tamburaka: 34). Ben Ali dan keluarganya melarikan diri ke Arab Saudi untuk menghindari tuntutan massa yang berhasil mengakhiri 23 tahun masa kejayaan kekuasaannya.

Keputusan Ben Ali untuk mundur dan meninggalkan Tunisia secepatnya karena dua faktor. Pertama, gerakan massa di seluruh negeri semakin kuat yang tidak lagi mampu dikendalikan oleh aparatur negara. Para demonstran, yang pada awalnya turun ke jalan sebagai bentuk solidaritas atas meninggalnya Bouazizi, selanjutnya menuntut pemecatan kepala aparat setempat Khaled Ghazouani di Kef. Ben Ali tentu menyadari bahwa kekuatan massa yang semakin besar melawan rezimnya akan berujung pada tuntutan pengunduran dirinya dari kursi kepresidenan dan kemudian dia akan dibawa ke pengadilan untuk mempertanggungjawabkan atas meninggalnya beberapa demonstran.

Kedua, dukungan Barat tidak datang pada masa krisis di mana dia sedang membutuhkannya. Bahkan Perancis tidak bersedia memberinya suaka politik sehingga Ben Ali akhirnya melarikan diri ke Arab Saudi. Presiden Barak Obama menyambut positif gerakan protes para demonstran. Tidak adanya dukungan Barat, terutama Amerika, yang dibutuhkan oleh Ben Ali karena Tunisia bukanlah negara yang menjaga kepentingan utama bagi Washington. Tunisia 
bagi Washington dan sekutunya adalah a peripheral interest. Tunisia tidak mempunyai suplai minyak yang banyak dan juga tidak ada gerakan Islam, yang menjadi ketakutan Washington dari The Arab Spring, yang siap merebut kekuasaan (Angrist, 2011: 80). Ekspor Tunisia juga lebih banyak ke pasar Eropa (71\%), bukan ke Amerika: Perancis (33 persen), Italy (24 persen), German (8 persen), dan Spanyol (5 persen) (A World Bank Country Study, 2009: 31).

Tumbangnya rezim kuat Ben Ali di Tunisia oleh gerakan kekuatan massa (people power), yang menjadi sorotan media di seluruh dunia, mempunyai efek domino terhadap negara-negara lain di dunia Arab. Efek domino tersebut karena faktor-faktor yang menjatuhkan rezim Ben Ali juga terdapat negara Arab lainnya. Bahkan, kondisi sosial, ekonomi, dan politik pada banyak negara Arab lebih parah jika dibandingkan dengan Tunisia (Kompas, 23/01/2011). Sebagian besar negara-negara Arab masih otoriter atau anti-demokrasi, untuk tidak menyebutnya depostik atau diktatorial. Inilah yang menjadi awal lahirnya perubahan di negara-negara Arab. Marc Lynch menuliskan "if Arab regimes refused to change, they would be change from below" (Foreign Policy: 41)

Rakyat dunia Arab sebelum peristiwa bakar diri oleh Bouazizi dihinggapi kebingungan, bahkan rasa putus asa mencari pintu menuju perubahan di tengah tertutupnya semua jalur politik serta penerapan sistem keamanan dan intelijen yang superketat. Oleh karena itu, aksi Bouazizi, yang ternyata dapat menjatuhkan rezim kuat Zine al-Abidin Ben Ali, membangkitkan semangat rakyat dunia Arab untuk melakukan perubahan di negaranya masing-masing (Kompas, 23/ 01/2011).

Berakhirnya era kekuasaan Ben Ali ini tersebar dan menjadi berita yang hangat di seluruh dunia Arab, bahkan dunia. Perlawanan rakyat Tunisia yang berhasil menggulingkan rezim diktator Ben Ali menjadi inspirasi bagi masyarakat negara-negara Arab lainnya untuk membangun kekuatan gerakan massa melawan rezim yang diktator. Dari sanalah gejolak revolusi, The Arab Spring, di Timur Tengah bermula.

Mesir termasuk salah satu negara yang terkena efek domino dari tumbangnya rezim Ben Ali di Tunisia. Beberapa hari setelah dunia mengetahui berakhirnya era Ben Ali, rakyat Mesir mulai turun ke jalan menuntut pengunduran diri Presiden Hosni Mubarak yang dinilai otoriter, korup, dan gagal membangun selama 30 tahun kekuasaannya. Rakyat Mesir menilai pemerintahan Mubarak sudah terlalu lama dan saatnya untuk diganti dengan pemimpin yang baru. Dukungan rakyat terhadap pemerintahan Mubarak sudah turun drastis karena kemiskinan dan pengangguran yang merebak luas. Harga-harga melambung tinggi, sementara daya beli semakin merosot. Sekitar 50 persen dari 81 juta penduduk Mesir hidup di bawah garis kemiskinan (Kompas, 28/01/2011).

Gerakan rakyat di Mesir memiliki kesamaan dengan gerakan rakyat di Tunisia. Gerakan ini tidak digerakkan oleh tokoh khusus, tetapi benar-benar dituntun oleh media sosial, seperti layanan pesan khusus melalui telepon seluler, Facebook, dan Twitter (Kompas, 28/ 01/2011). Kejadiannya juga hampir sama, yaitu ketika ada seorang pemuda Mesir bernama Khaled Said yang meninggal dunia akibat penyiksaan oleh intelijen Mesir (Syukur, 2013;71). Oleh karena itu, pemerintahan Presiden Mesir Hosni Mubarak merasa semakin terancam dengan bersatunya jutaan kekuatan rakyat menuntut dirinya mundur. Begitu khawatirnya akan aksi massa, otoritas berwenang pada hari Jumat (28/ 01/2011) menutup layanan internet dan telepon seluler serta mengerahkan pasukan elite bersenjata lengkap, termasuk tank dan mobil antihuru-hara. Satu hari sebelumnya, pemerintah sudah menutup akses situs jejaring sosial Twitter dan Facebook, juga Youtube, Yahoo, dan Google. Empat operator utama penyelia layanan internet di Mesir, yaitu Link Mesir, Vodafone,/Raya Telecom Mesir, dan Etisalat Misr mengaku layanan mereka telah ditutup pemerintah (Kompas, 29/01/2011).

Warga Mesir, yang sejak 25 Januari 2011 turun ke jalan menuntut pergantian rezim, akhirnya merayakan kemenangan pada Jumat malam, 11 Februari 2011, setelah mereka mendengar Wakil Presiden Omar Suleiman, melalui televisi, yang memberitahukan kepada seluruh warga Mesir bahwa Presiden Hosni 
Mubarak mengundurkan diri dan menyerahkan kekuasaan kepada Dewan Agung Militer. Revolusi rakyat Mesir pada saat itu mempunyai obsesi membangun sistem demokrasi di negaranya (Kompas, 13/02/2011).

Dua peristiwa besar yang menggulingkan rezim diktator kuat, Ben Ali di Tunisia dan Mubarak di Mesir, menyadarkan rakyat di negara-negara Arab bahwa mereka dapat membawa perubahan di negaranya tanpa harus mengandalkan bantuan AS atau komunitas internasional (Kompas, 16/02/2011). Berakhirnya era kekuasaan kedua diktator tersebut karena kekuatan dari bawah, people power, meskipun terbantu dengan adanya tekanan dari pihak luar. Oleh karena itu, setelah Mubarak dinyatakan mundur, demonstrasi-demonstrasi anti-pemerintah sudah terjadi di sejumlah ibu kota negara di kawasan Timur Tengah, seperti Aljazair, Yaman, dan Bahrain. Sejumlah pemimpin negara lainnya, seperti Suriah dan Jordania, mengantisipasi efek domino tersebut dengan menjanjikan dan melakukan serangkaian pembaruan ekonomi dan politik (Kompas, 16/02/2011).

Dampak dari kejatuhan kedua pemimpin tersebut adalah dengan munculnya kekuatan massa yang melakukan demonstrasi menuntut rezim yang berkuasa mundur dari kursi kekuasaannya. Dari beberapa negara yang terkena dampak dari gejolak yang berawal di Tunisia tersebut, hanya Suriah yang berlangsung paling lama, sampai hari ini. Negara-negara lainnya telah behasil meredam gerakan perlawana massa terhadap rezim tersebut.

Dalam kasus Suriah, kelompok oposisi, Dewan Nasional Suriah/Syrian National Council (SNC), yang mendapatkan dukungan dari Barat, dengan dalih perjuangan demokratisasi dan kemanusiaan, belum berhasil menggulingkan rezim Bashar al-Assad.

Negosiasi pun tidak pernah berhasil menemukan jalan keluar karena negosiasi dari pihak rezim al-Assad tidak ingin membahas posisi kepresidenan al-Assad. Adapun pihak oposisi menetapkan harga mati bahwa negosiasi bertujuan untuk menggulingkan rezim al-Assad. Kofi Annan, diplomat senior yang juga mantan Sekretaris Jenderal Perserikatan Bangsa-Bangsa (PBB), pernah diberi mandat sebagai utusan khusus PBB untuk perdamaian di Timur Tengah, namun Kofi Anan juga gagal menyelesaikan konflik politik di Suriah dan akhirnya mengundurkan diri sebagai utusan khusus PBB untuk perdamaian di Timur Tengah. Karena negosiasi selalu menemui jalan buntu, maka pertempuran antara rezim dan kelompok oposisi pun terus berlangsung sehingga korban, terutama dari rakyat sipil, terus berjatuhan.

\section{FAKTOR PENYEBAB THE ARAB SPRING}

Sebelum The Arab Spring bergejolak, ketiga negaranegara Arab tersebut (Tunisia, Mesir, dan Suriah) mempunyai beberapa kesamaan kondisi sosial ekonomi dan politik yang mempengaruhi The Arab Spring bergejolak. Pertama, ketiga negara tersebut masing-masing dipimpin oleh pemimpin otoriter yang berkuasa cukup lama serta pemimpin yang meraih kekuasaan dengan tidak melalui proses pemilihan yang demokratis. Di Tunisia, Ben Ali berkuasa sejak tahun 1987 melalui kudeta tidak berdarah. Ben Ali mengkudeta Habib Bourguiba setelah dia diangkat menjadi Perdana Menteri satu bulan sebelumnya. Di Mesir, Hosni Mubarak menjadi Presiden Mesir pada tahun 1981 setelah Anwar Sadat terbunuh, sebelumnya menjabat sebagai wakil presiden. Di Suriah, perjalanan Bashar al-Assad untuk menjadi Presiden Suriah karena menggantikan ayahnya, Hafez al-Assad, yang meninggal pada 10 Juni 2000. Jauh sebelum Hafez al-Assad meninggal dunia, Bashar alAssad sebenarnya sudah dipersiapkan untuk menggantikan ayahnya yang sudah tua.

Tariq Ramadan menambahkan bahwa rezim kediktatoran di negara-negara Arab sudah cukup lama memerlihatkan dirinya pada dunia sebagai kejahatan yang penting (a necessary evil), sebagai benteng pertahanan melawan kebangkitan gerakan politik Islam di Afrika Utara dan Timur Tengah secara lebih luas (Barakat: 13).

Kedua, ketiga negara tersebut membangun rezim politik dengan sistem satu partai; di Tunisia, Ben Ali menguasai panggung politik dengan Rassemblement Constitutionnel Demoecratique (RCD), di Mesir, Mubarak 
berkuasa bersama dengan partai Hizbul Wathan (HW), di Suriah, al-Assad menguasai panggung politiknya dengan dominasi partai Ba'ath. Ketiga, negara-negara tersebut mempunyai banyak catatan pelanggaran hak asasi manusia (HAM) serta membatasi ruang berekspresi kepada rakyatnya, termasuk dengan tidak adanya kebebasan pers. Keempat, krisis ekonomi dan pengangguran melanda rakyat yang dipimpinnya serta meningkatnya tingkat pengangguran. Hussein A. Hassouna juga mencatat bahwa mayoritas negaranegara Arab adalah negara sedang berkembang yang mana tingkat buta hurufnya sangat tinggi (Hassouna: 50-51). Data pada tahun 2009 menunjukkan bahwa tingkat buta huruf di Tunisia mencapai angkat 22,3, Mesir mencapai angka 33,6, dan Suria berada pada angka 16,9 (Ottaway, 2010: 52).

Oleh karena itu, gerakan massa yang berlangsung di negara-negara Arab mempunyai karakteristik yang sama, yaitu protes melawan kondisi sosial dan ekonomi, menolak kediktatoran, dan berjuang melawan korupsi (Ramadan: 7). Nadar Hashemi juga melihatnya demikian. Menurutnya The Arab Spring merupakan kelanjutan dari perjuangan dan pencarian panjang dari dunia Arab yang mayoritas Islam untuk dapat menentukan dirinya sendiri, lepas dari cengkeraman, baik dari luar (asing) maupun dari kekuatan otoritarian internal sendiri (the Arab Spring is the continuation of a longer struggle and quest by the ArabIslamic world for self-determination from both external and internal authoritarian forces) (Hashemi, 2013: 213).

Kondisi kemiskinan, pengangguran yang dirasakan sejak zaman kolonialisme hingga sekarang masih dialami. Padahal kawasan Timur Tengah memiliki sumber daya alam minyak yang melimpah. Sementara negara-negara tetangga mereka di kawasan Eropa telah menikmati kemakmuran di abad ke-20. Rata-rata pendapatan per kapita rakyat di kawasan Timur Tengah 2 dolar per hari. Kekayaan alam memang dikelola oleh negara, namun dikuasai oleh segelintir orang yang dekat dengan penguasa, termasuk aset-aset negara yang berupa perusahaan dan badan usaha. Sehingga kekayaan itu hanya menumpuk pada penguasa dan orang-orang yang dekat dengannya
(Tamburaka: 13)

Berangkat dari situasi sosial dan ekonomi politik yang terjadi dari ketiga negara tersebut, dapat dikatakan bahwa bergejolaknya The Arab Spring yang masih berlangsung hingga hari ini sebagai puncak dari gunung es akan harapan rakyat untuk hidup dengan kebebasan (demokratis). Hidup dalam tekanan, penderitaan, dan penyiksaan oleh rezim yang sewenangwenang yang terjadi pada diri Mohammed Bouazizi sebenarnya dirasakan langsung oleh rakyat Tunisia pada umumnya dan rakyat negara-negara Arab secara lebih luas. Oleh karena itu, gejolak The Arab Spring yang menjadi awal untuk mengakhiri rezim otoritarianisme dan bangkitnya ekspektasi publik untuk kehidupan yang demokratis di negara-negara Arab tidak terlepas dari kondisi sosial, ekonomi, dan politik yang dihadapi oleh ketiga negara tersebut.

Dalam membaca gerakan perlawanan oleh rakyat negara-negara Arab sejak 2011 lalu, L. Wilardjo memberikan analogi yang cukup menarik bahwa balon yang ditekan terus akhirnya meletus. Demikian pula masyarakat yang ditindas terus oleh penguasa akhirnya tidak tahan lagi, lalu pecahlah perlawanan (Wilardjo, 2014: 6). Teori Ign. Ismanto membenarkan hal tersebut. menurut Ismanto, setidaknya ada dua faktor yang memengaruhi berakhirnya rezim otoritarian, yaitu 1. Tekanan demokratisasi dari elemen-elemen yang berkembang seiring dengan perkembangan ekonomi. 2. Krisis ekonomi (Pito, dkk., 2006: 90).

Dalam teori perubahan sosial, The Arab Spring ini merupakan perubahan sosial yang datangnya dari free market (pasar bebas), bukan perubahan yang datang dari negara yang mana kita ketahui bahwa perubahan sosial itu merupakan keniscayaan. Membahasa perubahan social itu sendiri tidak dapat lepas dari konteks filsafat barat, yaitu suatu pandangan terhadap kemajuan manusia dalam masyarakat yang ditimbulkan oleh kemajuan masyarakatnya (Salim, 2002: 22).

Berangkat dari pemaparan di atas, penulis mengambil kesimpulan bahwa faktor bergejolaknya The Arab Spring sejak awal Januari 2011 lalu karena dua hal. Pertama, kelompok-kelompok intelektual yang bergerak untuk perubahan rezim (untuk demokrasi) 
Tabel 1: Kondisi sosial politik Negara-negara Arab

\begin{tabular}{|c|c|c|c|c|c|}
\hline NO. & NEGARA & $\begin{array}{l}\text { POPULASI } \\
\text { (JUTA) }\end{array}$ & $\begin{array}{l}\text { SISTEM KEPARTAIAN/ } \\
\text { AFILIASI POLITIK }\end{array}$ & $\begin{array}{l}\text { TINGKAT } \\
\text { BUTA HURUF }\end{array}$ & PELANGGARAN HAM \\
\hline 01. & Tunisia & $10,1(2009)$ & $\begin{array}{l}\text { Satu partai }(R C D) / \\
\text { berafiliasi ke Barat } \\
\text { (Eropa) }\end{array}$ & $22,3 \%$ & $\begin{array}{l}\text { 1. Pada tahun } 1991 \text { Ben Ali melarang Hizbut } \\
\text { En Nahda (Partai Kebangkitan) dan } 280 \\
\text { anggotanya diadili. } \\
\text { 2. Tahun 1994, Moncef Marzouki, Jenderal } \\
\text { Liga Hak Asasi Manusia, ditahan. Saat The } \\
\text { Arab Spring bergejolak, setidaknya } \\
\text { adakurang lebih } 1.000 \text { tahanan politik Ben } \\
\text { Ali. }\end{array}$ \\
\hline 02. & Mesir & 80,1 (2009) & $\begin{array}{l}\text { Satu Partai } \\
\text { (HW)/berafiliasi ke } \\
\text { Barat (AS) }\end{array}$ & $33,6 \%$ & $\begin{array}{l}\text { 1. HRW melaporkan adanya pelanggaran } \\
\text { HAM serius pada tahun } 2006 \text {. } \\
\text { 2. Pada tahun } 2007 \text {, Amnesty } \\
\text { 3. International merilis laporan penyiksaan } \\
\text { dan penahananan illegal di mesir }\end{array}$ \\
\hline 03. & Suriah & 20,5 (2009) & $\begin{array}{l}\text { Satu Partai } \\
\text { (Ba'ath)/berafiliasi ke } \\
\text { Timur (China, Rusia, } \\
\text { dan Iran) }\end{array}$ & $16,9 \%$ & $\begin{array}{l}\text { 1. Penangkapan sejumlah aktivis reformis } \\
\text { tahun } 2001 \\
\text { 2. Pembantaian terhadap etnis kurdi } 2004\end{array}$ \\
\hline
\end{tabular}

sudah lama tumbuh dan terus bergerak untuk membangun kesadaran masyarakat. Selain itu, inisiatiinisiatif untuk membangun sistem kehidupan berbangsa dan bernegara yang demokratis di negaranegara Arab sudah dilakukan, baik itu datangnya dari piahk luar (asing) maupun dari internal. Hal itu terlihat bahwa pada tahun 1994, Liga Arab telah menerima Piagam Hak Asasi Manusia/human right charter. Langkah ini merupakan salah satu upaya untuk membangun sistem pemerintahan yang terbuka (transparan), akuntabel, dan membuka ruang bagi masyarakat untuk berpartisipasi dalam dunia politik. Maka dari itu, Nader Hashemi berpandangan bahwa The Arab Spring memungkinkan untuk diistilahkan "Fourth wave of Democratization", sebagai gelombang keempat demokratisasi (Hashemi, 2013: 207).

Halim Barakat memperkuat pandangan ini dengan mengatakan bahwa demokrasi sebenarnya telah menjadi tuntutan masyarakat Dunia Arab sejak tahun 1990-an. Hal ini juga diperkuat oleh hasil survei yang dirilis oleh Arab Human Development Report (AHDR) pada tahun 2003 yang menunjukkan bahwa 60 persen masyarakat dunia Arab mendukung demokrasi dan 80 persen yang menolak pemerintahan otoriter (Sau, 2004: 4233). Terkait dengan ini, Filipe R. Campante dan Davin Chor menuliskan yang melihat perkembangan cukup pesat dalam hal ekspansi pendidikan di dunia Arab dalam dekade terakhir. Di samping itu, juga terdapat teori yang mengatakan bahwa pendidikan memengaruhi secara positif perkembagan politik atau demokratisasi dari sebuah negara (Campante dan Davin, 2012: 168). Oleh karena itu, gejolak The Arab Spring sejak 2011 lalu tidak terlepas dari peran kaum intelektual di mana negaranegara Arab juga menunjukkan adanya kemajuan yang cukup pesat dalam ekspansi pendidikan.

Di Tunisia, misalnya, pada tahun 1995 Moadda, kelompok oposisi, mengirim surat terbuka kepada Ben Ali yang memprotes praktek korupsi, otoritarianisme, dan tidak adanya ruang kebebasan dalam berpolitik di Tunisia. Ben Ali, menjelang pemilihan tahun 1994, juga pernah mengatakan bahwa ia akan membangun politik dengan sistem multi-partai di Tunisia. Ia juga mengatakan kepada publik bahwa demokratisasi tidak 
bisa tercipta dengan proses yang sangat cepat, tetapi harus dengan perlahan-lahan dan proses perubahannya secara terorganisir (Murphy: 215-230). Maka dari itu, Rami G. Khouri berpendapat bahwa The Arab Spring bukanlah ledakan politik yang datang secara tiba-tiba atau spontan, The Arab Spring adalah kelanjutan dari perjuangan yang cukup panjang akan harkat dan hakhak warga di negara-negara Arab (Laipson and Friends, 2011: 6).

Di Mesir, pada tahun 2000, mulai muncul dalam pembicaraan apa yang disebut infitah-keterbukaan ke arah Barat, perdamaian dengan Israel, dan pengadopsian model kapitalis neo-liberal sebagai kunci kesejahteraan bangsa Mesir (Kuncahyono: 89-90). Sementara itu, di Suriah, muncul gerakan yang disebut "Damascus Spring" pada awal pemerintahan Bashar alAssad. "Damascus Spring" adalah sebuah gerakan pembaharuan yang semula diberi tempat oleh Bashar al-Assad, tetapi tiba-tiba dalam sekejap dilarang dan "Damascus Spring" berubah menjadi "Damascus Winter". Meski "Damascus Spring" hanya berumur pendek, tetapi benih-benih tumbuhnya kelas menengah yang tercerahkan sudah mulai muncul dan tetap tumbuh walau secara diam-diam. Pada bulan Oktober 2005, sebanyak 250 tokoh oposisi bersama-sama mendeklarasikan apa yang disebut "Damascus Declaration" (Deklarasi Damaskus). Juga ada kelompok gerakan yang menyebut dirinya "Friends of Civil Society," yang membuat petisi, juga dikenal dengan istilah Manifesto 1000 , yang menuntut terciptanya pluralisme politik di Suriah (Ghadbian, 2001: 636).

Komunitas-komunitas intelektual ini mempunyai pengaruh yang sangat besar sebagai faktor utama dari bergeraknya perlawan massa terhadap rezim. Komunitas-komunitas intelektual itulah yang membangun kesadaran rakyat untuk melawan rezim yang menindasnya selama berpuluh-puluh tahun. Merekalah yang sudah cukup lama bergerak untuk membangun kesadaran public serta mengambil langkah-langkah inisiatif untuk melakukan perubahan social, termasuk dengan inisiatif untuk membangun pranata politik yang demokratis. Peran tokoh intelektual memang tidak bisa dinafikan dalam sebuah gerakan perubahan sebagaimana yang dikatakan oleh Edward Said bahwa tidak ada revolusi penting dalam sejarah modern yang tanpa melibatkan intelektual; sebaliknya, setiap gerakan akbar kontra-revolusi juga selalu melibatkan intelektual. Intelektual telah berperan sebagai ayah dan ibu sebuah gerakan (Said, 2014: 7). Hal itu karena intelektual, menurut paham Said, adalah 'pencipta sebuah bahasa yang mengatakan yang benar kepada yang berkuasa.' The Arab Spring yang mulai bergejolak pada awal tahun 2011 lalu tidak terlepas dari peran intelektual tersebut. merekalah yang terus bergerak menggugah kesadaran publik akan penindasan oleh rezim yang berkuasa, baik itu di Tunisia, Mesir, dan Suriah.

Kedua, peran media massa. Peran media, selain peran intelektual, sangatlah besar dalam gejolak The Arab Spring di negara-negara Arab yang berlangsung sejak awal 2011 lalu. Karena media memainkan peran kunci itulah sehingga beberapa pengamat menyebutnya dengan istilah "Internet revolutions" (Ramadan: 45). Media massalah yang berfungsi secara efektif dan masif menyampaikan protes dari rakyat terhadap rezim Ben Ali di Tunisia ke seluruh negara-negara Arab, bahkan dunia.

Pemberitaan media itulah yang membangkitkan kesadaran dan gerakan yang sama di beberapa negaranegara Arab, termasuk di Mesir dan Suriah. Eric Goldstein berpendapat bahwa ada beberapa faktor yang mendorong lahir dan berlangsungnya protes yang berawal di Tunisia, salah satunya adalah proses pemberitaan dari Al Jazeera yang berlangsung terusmenerus yang diambil dari hasil peliputan rakyat biasa melalui telepon dan kamera yang kemudian disebar melalui YouTube dan Facebook (Goldstein: 69).

Vitalnya peran media juga terlihat bahwa pada tanggal 18 Januari 2011, Asmaa Mahfouz, seorang aktivis muda, menyebarkan video lewat Youtube di mana dia berbicara kemenangan rakyat Tunisia melawan rezim Ben Ali di Mesir dan mengajak rakyat Mesir untuk melakukan hal yang sama dengan apa yang dilakukan oleh rakyat Tunisia. Asmaa, melalui video rekamannya, juga berjanji untuk mendatangi lapangan Tahrir Square pada tanggal 25 Januari $2011 \mathrm{demi}$ 
menuntut hak-haknya. Tujuannya adalah memobilisasi rakyat Mesir, di luar afiliasi politik, untuk berdiri melawan kebrutalan polisi, sejumlah tindakan eksekusi, dan perlakuan tidak manusiawi. "If you have honor, dignity, and courage, join me in liberation Square," katanya dalam video yang diunggahnya (Ramadan: $27-$ 28). Di samping itu, gerakan untuk mendukung Khalid Said, pemuda Mesir yang meninggal karena penyiksaan oleh intelijen Mesir, juga semakin hari semakin banyak, melalui Facebook, dalam sebuah grup yang bernama Kulluna Khalid Said (Kita Semua Khalid Said) (Syukur: 71).

Memahami vitalnya peran media dalam membangkitkan gerakan perlawan dari rakyat itulah sehingga pemerintah Mesir, sebelum lengsernya Mubarak, mengambil kebijakan menutup akses layanan internet, telepon, email, dan layanan dunia maya lainnya. Pada minggu pertama Februari 2011, tiga reporter Al-Jazeera juga ditangkap oleh aparat keamanan (Khalil, 2011:88). Langkah politik yang diambil Mubarak, sebelum dipaksa mundur oleh gerakan massa, ini sebagai upaya antisipasi rezim Mubarak dalam membendung gerakan massa yang dimediasi oleh media massa.

Oleh karena itu, keberhasilan masyarakat Mesir mengakhiri kekuasaan Mubarak dapat dikatakan sebagai buah kemenangan media sosial. Aksi jalanan oleh ribuan massa yang mengubah peta perpolitikan di negara-negara Arab tidak dapat dilepaskan dari gerakan yang dirintis melalui dunia maya, termasuk melalui Facebook. Wael Ghonim, tokoh kunci gerakan oposisi Mesir yang juga eksekutif Google, mengatakan bahwa semuanya dimulai dari gerakan online. "Revolusi ini dimulai dari Fecebook,” katanya (Gause III, 2011:86).

\section{KESIMPULAN}

Dari pemaparan di atas kita dapat menarik kesimpulan bahwa The Arab Spring yang bergejolak sejak awal 2011 lalu menjadi awal kebangkitan gerakan massa untuk menuntut adanya perubahan tatanan sosial politik. Peristiwa politik penting di negara-negara Arab tersebut terjadi karena banyak faktor yang terlibat memengaruhi, yaitu peran kelompok-kelompok intelektual, baik itu di Tunisia, Mesir, dan Suriah, serta pengaruh dari media sosial. Selain itu, efektifnya peran kedua faktor tersebut juga didukung dengan situasi sosial ekonomi dari ketiga negara tersebut yang mana dari data yang ditunjukkan di atas memerlihatkan bahwa tingkat pengangguran dan buta huruf cukup tinggi. Hal lainnya yang terjadi dari ketiga negara tersebut adalah banyak kasus-kasus pelanggaran HAM yang melibatkan negara (rezim).

Oleh karena itu, gerakan kelompok intelektual dan media sosial sejalan dengan harapan perubahan dari masyarakat bawah, yaitu harapan untuk kehidupan yang lebih baik dan lebih ideal. Masyarakat dunia Arab meyakini bahwa kehidupan yang ideal itu adalah dengan terbangunnya sistem politik yang demokratis. Maka dari itu, demokratisasi menjadi bagian yang tidak terpisahkan dari The Arab Spring.

Hal itu karena The Arab Spring (Musim Semi Arab/ al-Rabi' al-Arabiy) dipahami sebagai musim yang menjadi titik awal pertumbuhan demokrasi di negaranegara tersebut, meskipun tidaklah mudah untuk membangun pranata politik yang demokratis. Ia diperhadapkan dengan berbagai macam tantangan. Satu hal yang pasti bahwa The Arab Spring telah membuka pintu perubahan tatanan politik dan kehidupan masyarakat dunia Arab.

\section{DAFTAR PUSTAKA}

BUKU DAN JURNAL:

Angrist, Michele Penner, "Morning in Tunisia. The Frustrations of the Arab World Boil Over". Dalam The New Arab Revolt, What Happened,What It Means, and What Comes Next. New York: Council on Foreign Relation, 2011.

A World Bank Country Study, "Tunisia's Global Integration, A Second Generation of Reforms to Boost Growth and Employment". Washington: The World Bank, 2009.

Barakat, Halim, “Dunia Arab, Masyarakat, Budaya, dan Negara”. Bandung: Nusa Media, 2012.

Campante, Filipe R. dan Davin Chor, "Why Was The Arab Wolrd Poised for Revolution? Schooling, Economic, Opportunities, and the Arab Spring". Source: The Journal of Economic Perspectives, Vol. 26, No. 2 (Spring 2012), pp. 167-187. Published by: American Economic Association, 2011.

Gause III, F. Gregory, "Why Middle East Studies Missed the Arab Spring: The Myth of Authoritarian Stability". Source: Foreign Affairs, Vol. 90, No. 4 (JULY/AUGUST 2011), pp. 81-84, 85-90. Published by: Council on Foreign Relations, 2011. 
Ghadbian, Najib, "The New Asad: Dynamics of Continuity and Change in Syria". Source: Middle East Journal, Vol. 55, No. 4 (Autumn, 2001), pp. 624-641. Published by: Middle East Institute, 2001.

Goldstein, Eric, "A Middle-Class Revolution, dalam buku Revolution In The Arab World". Washington: Foreign Policy, 2011.

Joseph, Suad, "MESA Presidential Address 2011". Source: Review of Middle East Studies, Vol. 46, No. 1 (Summer 2012), pp. 623Published by: Middle East Studies Association of North America (MESA), 2011.

Khalil, Ashraf, "February 3: Swords VS. Pen. Dalam buku Revolution In The Arab World". Washington: Foreign Policy, 2011.

Laipson, Ellen and Friends, "After The Revolts". Source: The Wilson Quarterly (1976-), Vol. 35, No. 4 (AUTUMN 2011), pp. 6-7. Published by: Wilson Quarterly, 2011.

Murphy, Emma C., "Economic and Political Change in Tunisia, From Bourguiba to Ben Ali". New York: ST. Martin's Press, Inc, 1999.

Ottaway, David B., "The Arab Tomorrow". Source: The Wilson Quarterly (1976-), Vol. 34, No. 1 (WINTER 2010), pp. 48-64. Published by: Wilson Quarterly, 2010.

Pito, Toni Andrianus, dkk., "Mengenal Teori-Teori Politik. Dari Sistem Politik sampai Korupsi". Bandung: Penerbit Nuansa, 2006.

Ramadan, Tariq, "Islam and the Arab Awakening". New York: Oxford University Press, 2012.

Said, Edward. W., "Peran Intelektual”. Jakarta: Obor, 2014.

Salim, Agus, "Perubahan Sosial, Sketsa Teori danMetodologi Kasus Indonesia". Yogyakarta: Tiara Wacana, 2002.

Syukur, Yanuardi, "Presiden Mursi, Kisah Ketakutan Dunia pada Kekuatan Ikhwanul Muslimin”. Yogyakarta: Hayyun Media, 2013.

Tamburaka, Apriadi, "Revolusi Timur Tengah, Kejatuhan Para Penguasa Otoriter di Negara-Negara Timur Tengah". Yogyakarta: Penerbit Narasi, 2011.

Wilardjo, L., "Kekuatan Pengimbang". Kompas, edisi 13 September 2014. Kolom opini.

Salim, Agus, "Perubahan Sosial, Sketsa Teori dan Refleksi Meotodologi Kasus Indonesia". Yogyakarta: Tiawa Wacana, 2002.

Sau, Ranjit, "Democracy and Reform: Voices in West Asia". Sumber: Economic and Political Weekly, Vol. 39, No. 38 (Sep. 18-24, 2004), pp. 4232-4234.

\section{KORAN:}

Kompas, edisi 23 Januari 2011. Roboh Seperti Teori Domino.

Kompas, edisi 28 Januari 2011. Mesir Terkena Efek Tunisia. Hal. 6.

Kompas, edisi 29 Januari 2011. Mubarak Terancam.

Kompas, edisi 13 Februari 2011. Euforia Semalaman di "Alun-alun Kemerdekaan" Kairo.

Kompas, edisi 16 Februari 2011. Gelombang Demokratisasi di Timteng. Hal. 6.

Kompas, edisi 9 Desember 2015. Menanti Fajar Harapan yang Tak Kunjung Terbit. Hal. 9. 